
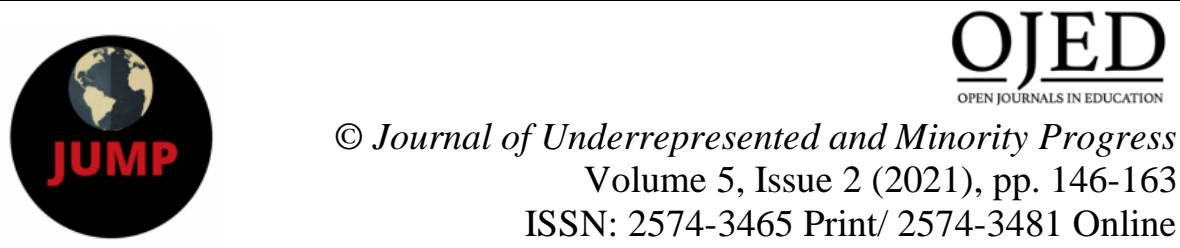

(C) Journal of Underrepresented and Minority Progress Volume 5, Issue 2 (2021), pp. 146-163 ISSN: 2574-3465 Print/ 2574-3481 Online http://ojed.org/jump

\title{
The Struggle of Ethno-Religious Minorities in Iraq: The case of Kaka'is
}

\author{
Nazdar Qudrat Abas \\ Garmian University, Kurdistan-Iraq \\ Dilshad Jaff \\ University of North Carolina at Chapel Hill, USA \\ Hashem M. Karami \\ Garmian University, Kurdistan-Iraq.
}

\begin{abstract}
Kakaism, a minority religion primarily found in Kurdish regions of western Iran, and eastern and northern Iraq, is a case of ethno-religious struggle. Kaka'is practice is an ancient faith, deeply rooted in the Metric religion, which can be traced back to 5,000 years B.C.E. Followers of the faith have been exposed to violence, armed conflicts, and atrocities, and deprivation from the four pillars of the minority rights: the right to exist, the right to non-discrimination, the right to protection of identity, and the right to civic participation. Although the focus of this paper is on the struggle of Kaka' is in Iraq, the comments and conclusions might be relevant for similar contexts in which ethno-religious minorities are oppressed.
\end{abstract}

Keywords: ethnicity, human rights, Iraq, Kaka'is, religious minorities, Yarsan. 


\section{INTRODUCTION}

Iraq has been the birthplace and, for millennia, the home of many religions and faiths such as the Abrahamic religions and Baha'ism, Kakaism, Sabeans, Yazidism, and Zoroastrianism. In addition, the region is a homeland for many ethnic groups such as Arabs, Kurds, Turkmens, and other minorities (Al-Harzany, 2007).

Kaka'is, a Kurdish ethnic group, follow Kakaism, which is a syncretic religion with about 5,000,000 members found primarily in western Iran and eastern and north Iraq. The International Minority Groups Right estimated the number of Kaka'is at 200,000 inhabitants in Iraq (Minority Rights Group International, 2018; Hosseini, 2017). Despite the decades-long existence of this ethno-religious group, not much is known about them due to the scarcity of literature on Kaka'is. Available information about their beliefs, rituals, and religious identity are inaccurate because it was written mainly by scholars not affiliated with the group, as many members of the group do not share their faith freely. This minority in Iraq has never been formally recognized as an independent religion in the Iraqi constitution and they are registered as Muslims on their national identity cards.

According to Henrard (2000), a minority population is "a group with ethnic, religious, and linguistic characteristics differing from the rest of the population, which is non-dominant, numerically smaller than the rest of the population and has the wish to hold on to its separate identity" (p. 48). Article 27 of the International Convention on Civil and Political Rights (ICCPR) set out minority rights, which was developed further in the Declaration on the Rights of National or Ethnic, Religious or Linguistic Minorities (UNDM) and afterward was adopted by the United Nations (UN) General Assembly in 1992 (Chapman, 2008). Minority rights are presented in the form of four pillars: (1) the right to exist, (2) the right to nondiscrimination, (3) the right to protection of identity, and (4) the right to participate in public affairs.

Despite the fact that most ethnic, religious and sectarian minorities are recognized in the constitution, these minorities cannot have or practice their basic rights (UNPO, 2003). Unfortunately, minorities, such as Kaka'is, which suffered severe discrimination and atrocities throughout Iraq's modern history do not receive political protection like other minorities such as Yazidies and Christian despite the creation of a democratic constitution in Iraq in 2005 (Iraq Const. art. IV). Their vulnerability and suffering have become extreme during the political upheavals of the last decades, especially due to their exclusion in the formation of countries and the 
drawing of borders in modern history in the Middle East after the World War I. (Lamani, 2009).

For the reasons above, the group is understudied and not understood well. By addressing the case of Kaka'is, this article aims to underline the struggles of ethno-religious minorities in Iraq.

\section{WHO ARE THE KAKA'IS?}

Members of the Kurdish ethnic group follow several religions. Kakai' is are a Kurdish ethnic community with a religion that is distinct from other religions and minorities in Iraq. Kaka' $i$ is known as Yarsan, God beloved, or Ahl-e Haqq, People of Truth in Iran and as Kaka'i brotherhood in Iraq (In Arabic "Kaka'i" or "Kaki"). Kaka'is have their own holy book called Saranjam, speak Gorani dialect of Kurdish, and believe in Reincarnation, which is a philosophical concept that holds as a main idea of living being starts a new life in a different physical body or other physical forms following their biological death (Gross, 1993; Laumakis, 2008; Anwar, 2018; Fahmi Kakai, 2018). Music is an important part of their religion; it is involved in their religious practices (Hawramy, 2011). The emergence of the Kakai religion dates back to more than 5,000 years. According to historical and scholarly sources, the roots of this religion extend to the Metric religion, which emerged within Kurdish populations (Amin, 2015; Falak al Din Kakai, 2013; Kreyenbroek, 2015).

Kaka'is, Yazidis, Muzidiks, Druze (in Lebanon and Syria), Alawite, and Shabaks are the remnants of Yazdan religion, which was one of the main pre-Islamic religions of the Kurds (Foltz, 2013). The ancestors of the Macedonian Kurds were adherent to the Yazdani religion, the official religion of the Median Empire more than 3,500 years ago. This indicates that Kakai religion is much older than the Zoroastrian religion (Wang Haoyu, 2012). The Median Empire (708-550 BC) is the first empire to appear in the history of ancient Persia, which are now the northern and northwestern areas of Iran. The Medians appeared at a time when the ancient Near East region was a battlefield between the powerful Empires of the Assyrians, the Hittites, the Egyptians, and the Kingdom of Urartu (Armenia). Scholars suggest that the Medias were the ethnic origin of Kurds today (Özoğlu, 2004). The history of the Median Empire can be divided into the era of evolution, prosperity, force and expansion, and fall and dependency (Ali, 2011).

Kakaism is an ancient religion deeply rooted in history. Most references report that the religion was founded in the late 14th century in western Iran by Sultan Sahak, but its history is older. According to Kaka'i 
holy book (Saranjam), God had planned this religion even before creating earth and the sun. The history of Kakaism is composed of four main epochs: First Epoch, or Shari'at, also known as the Prophet period, is the period from Adam and Eve until Ali ibn Abi Talib, the cousin and son-in-law of Muhammad and the last Caliph of Islam (Juergensmeyer \& Roof, 2011). The Second Epoch, or Tariqat, also known as the Doctrine period, is from from Ali ibn Abi Talib until Shah Khoshin, or Mubarak Shah. The Third Epoch, or Marefat, also known as the Mystical period, includes the period from Shah Khoshin until Baba Nawis (Shawais, 2011). The Fourth Epoch, or Haqiqat, also known as the Truth period, includes the period from Baba Nawis until Sultan Sahak, who is the youngest son of Sheikh Esa Barzanji. As per Kaka'is holy book Saranjam, Sultan Sahak (or San Sahak) lived from 675 to 798 of the Hijri Islamic calendar and was born to a virgin mother (Diarak or Ramzbar) in Barzanja village in Halabja governorate in the Kurdistan Region of Iraq (KRI) (Anwar, 2013).

In present day Iraq and KRI, Kaka'is mainly inhabit Kirkuk; but also live in Diyala, Erbil, Sulaimaniyah, and Mosul (Salloum, 2013, 2015, 2017). Kakai holy places are located in Iraq and Iran. Kakaism have four major pillars to their beliefs, which are purity, honesty, humility and tolerance. Purity means to be pure and clean inside and outside. Honesty is to follow right path as God orders. Humility is to be modest, control one's own desires, and avoid arrogance. Tolerance means to be patient and ready to sacrifice for others, and endure difficulties.

It is considered a religious duty to keep their religion secret due to the fear of social environment and other ethnic groups' reactions, which has clearly underpinned such secrecy and reticence. Kaka'i men are easily distinguishable due to their characteristic mustaches. Kaka'is holy book Saranjam states shaving is a sin, which also renders them more exposed to harassment and discrimination.

\section{IMPROPER PERCEPTIONS AND MISCONCEPTIONS ABOUT KAKA'IS}

There are many misconceptions about Kakaism and Kaka'is among other religious groups in Iraq. These misconceptions are primarily due to the secrecy of its followers about their faith. This resulted in false beliefs held by the population, with many unsound perceptions and fabricated stories being circulated. The ambiguity has also remained an obstacle for scholars trying to explore and document the religion, its rituals, and beliefs.

The most common misconception about Kaka'i is its affiliation with Islam (Al Khoa'i, 2017) and being a part of Shia'ahism. Kaka'i is an 
independent religious group (Lalani, 2010). It is also misbelieved that Kaka'is fast in the last three days of the month of Ramadan; the twenty seventh, twenty eighth, and twenty ninth, and celebrate Eid Al-Fitr festival like Muslims on the thirtieth day (Robins \& Tremewan, 2004). However, in practice, Kaka'is fast is only three days in the middle of winter and their ritual has no relation with Ramadan.

Another misconception is that the faith group is accused of being devil worshippers, although in reality the followers believe in God. The fact that they do not share a lot about their faith makes people from other faiths to share false assumptions and conclusions based on personal false explanations (Robins and Tremewan, 2004).

The third source of misconceptions is regarding the religious rituals of Kaka'i followers, especially during the period of their annual fasting. Usually, Kaka'i followers gather collectively to practice their religious ceremonies and rituals, but some people from other faiths believe or think they are practicing group sex (Al-Ezawy, 1949).

Certain misconceptions have emerged in scholarly work as well. Van Bruinessen (1995) mentioned that Sultan Sahak disappeared or died and re-appeared or reborn in the form of Haji Bektash by reincarnation. It is important to clarify that Haji Baktash was not Sultan Sahak but the prophet of Baktashi belief - a Sufi and mystical teaching based on tolerance, esoteric interpretation and on the love of Ali ibn Abi Talib, a caliph, cousin, son-inlaw and companion of the Islamic prophet Muhammad. Rostam (2006) has also exaggerated the role of Ali ibn Abi Talib in Kaka'i religion. For instance, the author has mentioned that Adam was made the same as Ali ibn Abi Talib and that after Ali ibn Abi Talib died, his soul entered the sun, therefore Kaka'is respect and prostrate themselves to the sun. In Kaka'is belief, Ali ibn Abi Talib did not exist yet when Adam was created. His soul did not enter the sun, but the sun is one of God's angels called Kala Zarda (i.e., yellow ox) (Hawary, 2021). Robins and Tremewan (2004) have mentioned misleading information about Kaka'is such as describing Ali ibn Abi Talib as their prophet. To further clarify, Kaka'is have more than one prophet according to each epoch, as we mentioned earlier.

Furthermore, it is falsely believed that Kaka'is exist in Karbala. It is very rare to find Kaka'i families living there. The Kaka'is made their pilgrimage to Sultan Prdeawer/prdeəwær/ in the north of Iran (Kreyenbroek et al, 2017).

Divorce is as mutually agreed upon as marriage in Kaka'i religion. Some other Kaka'i traditions are also taken from the community and the culture they have lived in for centuries. These traditions might lead to dissolving 
their original religious identity because most of the customs and cultural practices that they have gotten from the cultures they live with are completely against their religious rules such as polygamy, female genital mutilation, honor killing or gender inequality (Sadoon, 2018).

\section{KAKA'I DURING MODERN MIDDLE EAST HISTORY}

After the establishment of the Persian Empire, also known as the Achaemenid Empire (550-336 B.C.E.), the Persian rulers succeeded in forcing a small percentage of the Yazdani Kurds to embrace Zoroastrianism, the official religion of Persian Empire (Jackson, 2003). The majority of the Kurds, however, remained with the remnants of the Yazdani religion (Mahdi Kakei, 2017; Mohammed, 2018). After the emergence of Islam and the invasion of the region by Muslim conquerors, the Yazidian religion struggled to oppose the Persian political Zoroastrianism and the Islamic doctrine (Fahmi Kaki, 2018). In the second half of the 16th century, the majority of the Kurds, including people practicing the branches of the Yazdani religion (Kakaism, Yazidis, Muzidiks, and Druze), were forced to become Muslims, adopt various Islamic symbols then adding them to their beliefs and to their holy books to protect themselves from murder, captivity, injustice and humiliation. The branches of the Yazdaniyah religion stood strongly and resisted all the pressures and oppressions. It was a source of a valuable consolidation in Kurdish society and important aspects of the culture, language, heritage, and history of the Kurdish people were maintained by the followers of these religions. Similarly, the holy books are in Kurdish and they are considered as an ancient Kurdish religion (Mohammed, 2018).

In modern history of Iraq, there were lots of attempts to report the Kaka'is (Yarsani) as Muslims because scholars and authors who wrote about them were from outside the religion (Rostam, 2006). On the other hand, Kaka'is are also very protective of sharing their own beliefs and details about their religion. According to historian Mahdi Kakei, most of the Middle Eastern history is written by rulers or by biased people, who have changed and misled the religious and ethnic principles of the community for their own purposes (Mahdi Kakei, 2017). In the Iraqi census in 1957, for example, practitioners of many religions and ethnicities were forced to change their religious identities to Islam.

Kaka'is have never been formally mentioned as an independent religion in the Iraqi constitution mainly because the majority of this group wants to keep their faith secret. They are registered as Muslims on their national identity cards. Therefore, some Kaka'i members started a campaign 
to be acknowledged as Kaka'is in the Iraqi constitution of 2005, and recognized as an independent religious group on the national identity cards. Another group disagreed with the campaign, as they believed that it would expose Kaka'is to greater risks. However, others within the faith group know that Kaka'is are already persecuted, and if they do not protect their identity, their religious beliefs, religion, and traditions might disappear and fade away over time (Svirsky, 2016).

During Saddam Hussain's presidency, the Kaka'is suffered systematic violence, discrimination, and subjugation because of their Kurdish ethnicity. They were forced to identify with the Arab ethnicity instead of insisting on maintaining their Kurdish ethnicity. Most of their communities were expelled to the desert in the west and south of Iraq. Furthermore, thousands were expelled to Iran (1.3 million refugees) and Turkey $(400,000$ refugees) (CDC, 1991). They were deprived of their cultural, linguistic, and religious rights (Daraj, 2018; Ibrahim, 2015). Because of the regime's Arabization policies, many Kaka' is were forced off their lands and villages, forcibly evicted from Kurdish regions and expelled to southern Iraq. In the provinces of Kirkuk and Diyala, Kurdish villages (Muslim and Kaka'is villages) were evicted forcefully. The residents of 26 Kakai villages in Khanaqin district in Diyala governate (see Figure 1), and were evicted to Iran and other parts of Iraq (Al-Ezawy, 1949; Qaytuli, 2008).

\section{Figure 1.}

Remnants of a Kaka'i Village in Khanaqin, which all families were evicted during the 1980s (Abas, 2019).

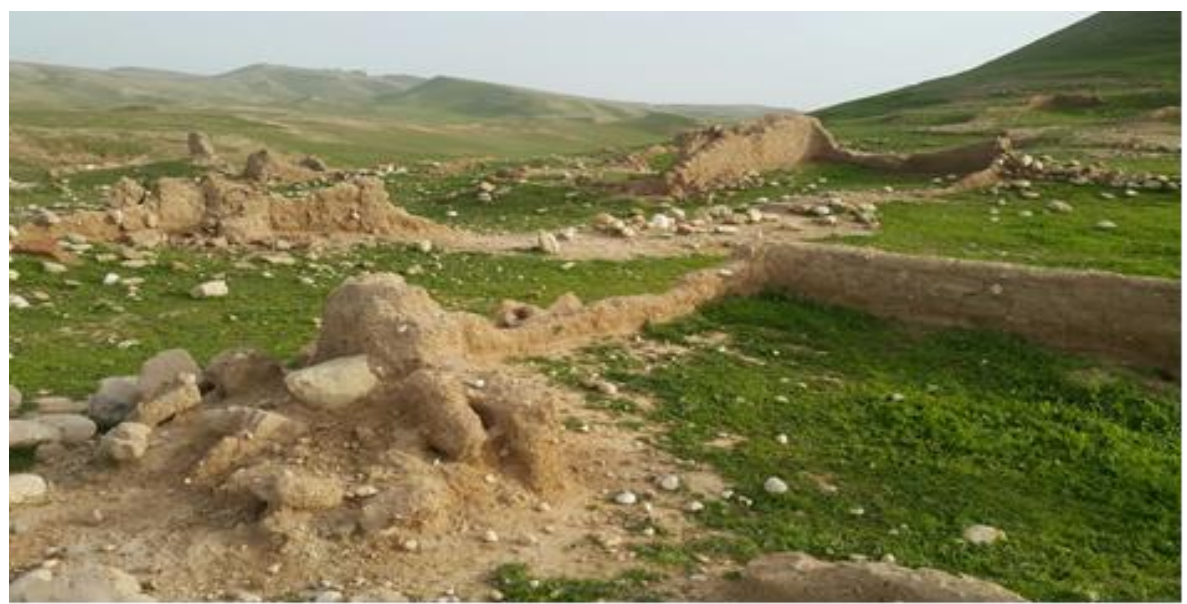


The government destroyed and erased Kaka'i villages along the Iranian border in Diyala governorate in order to create a security zone for the eight years during the Iran-Iraq war (Qaytuli, 2008). Hundreds of Kaka'is living in Kirkuk were forcibly exiled to Iran because of their Kurdish ethnicity, losing their nationality in the process (Minority Rights Group International, 2017). The Iraqi government transferred the ownership of their agriculture lands to Iraqi Arabs. Kurds lost ownership of their own lands and houses solely because of their Kurdish ethnicity. The only choice given to them by the Iraqi government was to change their ethnicity from Kurdish to Arabic in order to have their belongings and ownerships back (Assi, 2014).

\section{KAKA'I AFTER 2003}

In 2003, after the fall of the regime and the political changes in Iraq, minorities, especially the members of Kakaism, have continued to struggle. They became direct targets of political, economic, and religious violence. Kaka'is, like other minorities, have been targeted because of their ethnic or religious identity and have been forced to leave their homes (Lamani, 2009). Kaka'is' discreet beliefs and the falsified narratives about them have made them alienated from their social surroundings. Some Muslim religious leaders in Iraq deliver continuous sentiments against Kakaism by asking their followers not to interact with them or buy goods from their shops, describing them as devil followers. Despite the gravity of such hatred practices, the Iraqi government has never taken any steps to address these serious issues.

Discrimination against Kaka'is is mainly due to two compounded reasons. First, they are a religious minority, which the majority of Muslims consider as blasphemous. Second, because of their Kurdish ethnicity (Saadun, 2016).

Despite the existence of watchdog entities, such as the Institute for International Law and Human Rights (IILHR) in Iraq since 2005, Kaka'is have been subjected to threats, kidnapping and assassinations, mainly in Mosul, Kirkuk, and Diyala. Another difficulty that still exists today is due to the fact that some of Kaka'i families returned to Iraq after being deported to Iran by the Saddam Hussein regime. These families have various challenges obtaining Iraqi civil documents. In September 2007, four members of a Kaka'i family were forcibly arrested by armed groups near Baquba, center of Diyla governorate, where they were humiliated, severely tortured, and killed because of their faith and Kurdish ethnicity (Yari-Yarsan, 2013). In October 2009, a Kaka'i village (Tobzawa) south of Kirkuk was targeted with a 
suicide car bomb early in the morning which destroyed over 15 houses and caused about 30 individual injuries (Assi, 2014). Also, in Kirkuk city, Kaka'is faced much discrimination. Between 2003 and 2007, more than 150 Kaka'i families in the Uroba area were forced to move to other areas in or outside Kirkuk because of mistreatment, threats, and disputes by Muslims in the area. In 2006, many Kaka'is were assassinated in different areas of Kirkuk. Two Kaka'i college students were murdered. At their funerals, two suicide terrorists exploded themselves, which caused four more deaths and nineteen injuries (Assi, 2016). According to a media report, more than 250 Kaka'is have been killed since 2003 (Jamal, 2019).

\section{KAKA'I AFTER THE EMERGENCE OF ISIS IN 2014}

During the invasion of Mosul in 2014 by ISIS, about 1,038 Kaka'i families fled their homes in Mosul toward the Kurdistan Region of Iraq to avoid genocide. ISIS destroyed three religious' shrines of Kaka'is in Mosul and five villages were completely destroyed in the area during ISIS attacks. Several weeks after those attacks, and the Yazidi genocide by ISIS, a group of thirty religious Kaka'i men in Kirkuk declared themselves Muslims (Hosseini, 2018). The denial of the Kaka'is' religious identity was a clear sign of their fear of facing the same fate of the Yazidi people, since Kirkuk was under attack.

When ISIS attacked the disputed areas after taking control of Mosul, Kurdish Peshmarga and Iraqi forces shared safeguarding duties of the area, and the group was relatively protected. However, after the referendum for independence from Iraq by the Kurdish authorities in September 2017, and the withdrawal of Kurdish forces from Kirkuk and Diyala in October the same year, a big security vacuum in the region was created. Since early 2018, Kaka'is have been under systematic brutal attacks by different armed groups in the disputed areas, including the remnants of ISIS, especially in the villages south of Kirkuk.

While the intensity and frequency of these attacks are on the rise, the Iraqi military has left the area, increasingly putting this minority population in danger of being persecuted on daily basis. Kidnapping, murdering, explosions, threatening and destroying shrines is the new normal for the group in Iraq. These incidents have led most Kaka'is to leave their homes and villages. From 14 villages, only three Kaka'i villages are left in the area (Rudaw, 2020). In most cases, the perpetrators are not held accountable for their crimes and could escape justice. The Kaka'is are not able to fight radical armed groups with their personal weapons against their advanced weapons. Though they may be able to resist for a short time in 
case of any attack, previous attacks showed that the Iraqi Government forces arrived to the inflicted area after 8-10 hours during which much damage has already been caused (Almas, 2020a). This creates stress and panic among the Kaka'is in the area about the next attacks, as ISIS fighters are well trained, have advanced weapons, and attack in large numbers. While these atrocities are taking place regularly and have made many of Kakis to leave their villages, not much has been mentioned in the international media (Anwar \& Abdulla, 2021). The Kaka'is suffered from 15 different attacks in the first half of 2020, in Kirkuk, Nineveh, and Diyala. More than 10 Kaka'is were killed when a nationwide lockdown was in place. The Iraqi security forces are yet to ensure the safety of the Kaka'is as they have not been providing enough security for their villages that share border with territories where ISIS affiliated groups are active. Also, Iraqi authorities are preventing this population from having their own weapons to protect themselves and their families from these regular attacks (Almas, 2020b). This dangerous situation has affected the normal daily life for the Kaka'is in the area. The fears and stress from of being attacked at any moment make them mentally exhausted, especially the women and children.

Unfortunately, local authorities are ignoring calls for help and support from minorities. No one has yet been held accountable for these brutal acts that have been committed against the Kaka'is resulting in insult and injury. The Kaka'is believe that it is another attempt to Arabize their villages and is done in preparation to control more fertile lands rich with oil and other natural resources. Lately, many obstacles were created by the Iraqi government for Kurdish families in order to prevent them from returning to Kirkuk. Nevertheless, Iraqi Government facilitates the movement of Kurdish families out from Kirkuk. These recent developments led a group of Kaka'i organization leaders to ask for help and support for their people from the United Nations Assistance Mission for Iraq (UNAMI) to take serious steps in asking the Iraqi Government to protect Kaka'is and their villages from these armed groups in southern Kirkuk (Kirkuknow, 2020). However, some Kaka'is have expressed that after asking for help from UNAMI, the Iraqi Government sent some of its soldiers to the area before the UNAMI team arrived, and the severity of the situation was thus downplayed.

\section{DISCUSSION AND WAYS FORWARD}

It is clear that Kakaism has an ancient history and unique characteristics different from other religious groups in the region. Kaka'is are still not recognized in the Iraqi constitution and only little is known about them in Iraq. This is a serious gap in the legal framework for the protection of 
minorities in Iraq. According to an analysis by Gurr (1993), ignoring cultural identity, inequalities, and historical loss of autonomy all contribute substantially to grievances of minorities.

In view of the ongoing and worsening discrimination, there are now debates among Kaka'i religious figures about whether secrecy is helping or harming their ability to gain political rights and legal protections. Since the Iraqi constitution asserts that religious minorities have the right to protection, some are arguing that the Kaka'is would benefit from claiming their heritage and seeking recognition as a distinct religion with the right to protection and also to gain political-legal rights. Kaka'is are already exposed to violence and harassment without being formally declared as a religious minority. It is a primary and fundamental right of Kaka'i followers to have their religious identity recognized in Iraq and globally. Kaka'is should not face any threat or fear by telling the truth about their faith. Living in fear of disclosing identities has psychological consequences on their members, particularly children and young adults (Brown, 2015; Pascoe \& Richman, 2009; Schmitt et al., 2014).

Kaka'is have long been secretive about their religion, both as a religious obligation and also as a strategy for the community's selfprotection from being attacked. A group within the faith still defends the secrecy and disagrees about talking publicly about the faith for two reasons. First, their religion is considered a secret and declaring it counts a sin. Second, as most of the Iraqi population considers them infidels, this population is subject to lack of protection by the Iraqi authorities, and the group fears constantly for their safety from more violence and even genocide. They believe that in a country with a long history of battles and violations like Iraq, there is no guarantee that they would be safe and protected, even if they were formally reported as an independent religious minority. Yazidis, for example, are recognized as a religious minority in the Iraqi constitution, and yet they suffered an unforgettable tragedy by ISIS (Lamani, 2009). Some of the Kaka'i followers declare themselves to be Muslims to protect their community from persecution.

According to Minority Right Group International, Iraq ranks number four globally after Syria, Somalia and South Sudan for allowing minorities to witness and face genocide and mass killings (MRG, 2018). This makes their struggle to be recognized as an ethno-religious group more difficult. Furthermore, this leads local authorities and communities to associate the group with other religions and sects, such as the Shiite sect. Lamani (2009) has found that minorities in the Middle East are forced to indicate an affiliation that does not reflect their real identities because 
governments do not recognize their religion or ethnicity. Despite the existence of many organizations and institutions for human rights in Iraq, especially after 2003, they have not done their duty to protect Kaka'is and denounce various forms of human rights violations against them (UNAMI, 2019).

Minorities' political representation strengthens representational links with the government, creates positive attitudes toward government, and encourages the political participation of the community (Banducci et al., 2004). The absence of political representation of Kaka'is has led to a chasm between them and local authorities, made their voices unheard, and made it hard to address their needs. Iraq's minorities are on the verge of disappearance. Although Kaka'is have not declared their faith formally, they have long been exposed to violence and harassment throughout their history. The neglect of the Iraq government, the hatred and violently charged religious speeches against Kaka'is, the ignorance and intolerance of most of the population, and the lack of action by the Iraqi government, the international community, and organizations of human rights and minorities' rights groups have allowed the violence to continue against different groups and minorities in Iraq, including Kaka'is. Therefore, Kaka'is in Iraq feel ignored, insecure, and unprotected by the government. During the ISIS invasion of Mosul, the Iraqi government took no steps toward fighting the armed group or helping the hundreds of families who fled their homes toward the Kurdistan region. After September 2017, when Kaka'i villages in Kirkuk were left with no military protection and later were attacked, the Iraq Government turned deaf ears to the calls for help by the Kaka'is. When Kaka'is had their own soldiers to protect their own villages, the government did not support them financially.

This article demonstrates that all four pillars of minority rights have been violated for Kaka'is in Iraq. Kaka'is are still struggling to gain the right to be considered as an Iraqi ethno-religious minority group with a long history. The group has been discriminated against throughout the history by all subsequent governments since the foundation of Iraq. An example of the violation of Kaka'is' most primary rights is the missing religious identity. Kaka'is are reported as Muslims against their will. Furthermore, they have no role in political and public affairs in a democratic government and are completely neglected, denied their rights, and marginalized. The need for actions to restore the rights of Kaka'is and to enhance their protection has never been greater. Table 1 below summaries strategies and actions to be taken at national and community levels based on the findings of this paper and indicates the current gaps and challenges. We believe that protection of 
the group could be increased and achieved through the implementation of these recommendations.

\section{Table 1.}

Strategies/actions for Kaka'is to restore their rights and enhance their protection at national and community level:

\begin{tabular}{|l|}
\hline At national level \\
\hline Recognize Kakaism as a formal religion in Iraqi constitution \\
therefore to be protected as a minority. \\
\hline - \\
Create diverse educational programs at all levels and include \\
religious minorities. \\
\hline Develop new laws and regulations to guarantees the rights of \\
minorities in Iraq and the Kurdistan Region and protect them from \\
harm and harassment. \\
\hline Allocate parliamentary seats for Kaka'is to represent themselves in \\
the Iraqi and the Kurdish parliament as other minorities and groups \\
do. \\
\hline Bring to justice criminals and terrorists who committed atrocities \\
against minorities in Iraq should bring to justice and hold \\
accountable for their crimes. \\
Human Right organizations in Iraq need to take serious steps toward \\
protecting Kaka'is and other minorities' rights. \\
At community level \\
\hline -
\end{tabular}

\section{CONCLUSION}

Kakaism is a marginalized religious minority group in Iraq. Kaka'is have unique religious practices and rituals that give them a unique identity. They have experienced discrimination, atrocities, and have been ignored throughout history until today. Lack of scholarship about Kaka'is has made 
research and study of this group challenging. While other minorities in Iraq are demanding protection and rights, Kaka'is are still struggling for their right of religious identity to be recognized in the Iraqi constitution. The privacy about their religion and the fear of genocide and extinction have made this religion marginalized, overlooked, and forgotten. Kaka'is themselves are responsible for not declaring and claiming for their religious identity publicly. The Iraqi governments throughout modern history are responsible for not ensuring the welfare, and protection of this minority population. It is never too late for Kaka'is to demand their rights. Native Kaka'is and local scholars must study, document, and advocate for the group's identity to be recognized and its religious and cultural heritage to be protected and preserved.

\section{ACKNOWLEDGEMENTS}

The authors thank Professor Michele Rivkin-Fish for making suggestions on an earlier draft of the article.

\section{REFERENCES}

Abas, N. Q. (2019). Remnants of a Kaka'i village in Khanaqin." Name of the village: Qola-Syfia (photo). Taken by the first author during a visit to Kaka'i villages.

Al Khoa'i, J. (2017). Religious minorities in Iraq, History and beliefs. European Association for the Congregation of Religions.

Al-Ezawy, A. (1949). Kaka'is in history. First Edit.Tijara Company. 14-87.

Al-Harzany, N. Y. (2007). Kaka'is: anthropology of social life. (1st edition). Sulaimaniyah, Iraq. Master thesis, 1985 at University of Baghdad, Iraq.

Ali, A. H. (2011). The Medea State (550 - 708 BC) is the first country to appear in the history of ancient Iran. Journal of Iranian Studies, (13), 49-69.

Almas, M. (2020a). Kakai minority fights for life on two fronts. Kirkuk Now News. Access date: September 8, 2021. Retrieved from: https://kirkuknow.com/en/news/62093

Almas, M. (2020b). Kakais' anguish in search for security. Kirkuk Now News. Retrieved from: https://kirkuknow.com/en/news/62216

Amin, M. (2015). The Kaka'is: We pretend that we are Muslims and we want to abolish the religion on identity. Raise Your Voice "Radio". October 31, 2015.

Anwar, D., \& Abdulla, N. (2021). Local officials say Iraq's Kakais, fearing is, are fleeing their villages. Voice of America website. Access date: September 8, 2021. Retrieved from: https://www.voanews.com/extremism-watch/localofficials-say-iraqs-kakais-fearing-are-fleeing-their-villages 
Anwar, K. A. (2013). Kaka'i religion. University of Sulaimaniyah, Language and Human Sciences Faculty, Language School, History Department. Journal of Humanity Sciences; (55), 129-152.

Anwar, K. A. (2018). History of Yazidi and Kaka'i religion. 1st Edition. Taran Publication, Halabja, Kurdistan, Iraq. 146-148.

Assi, R (2014). Kakaism and confronting challenges in Kirkuk and Iraq. Mirory 4. (Iraq). December 19, 2014. Retrieved from: http://mirory4.blogspot.com/2014/12/alkakih-and-challenges-in-kirkukiraq.html

Assi, R. (2016). Reality of Kaka'is' Situation. Radio Sawa. Awraq Al-Sabah. (Iraq). August 2, 2016. Retrieved from: https://www.radiosawa.com/a/317409.html

Banducci, S. A., Donovan, T., \& Karp, J. A. (2004). Minority representation, empowerment, and participation. Journal of Politics, 66(2), 534-556.

Brown, C. S. (2015). The educational, psychological, and social impact of discrimination on the immigrant child. Washington, DC: Migration Policy Institute.

Bruinessen, V. M. (1995). When Haji Bektash Still Bore the Name of Sultan Sahak. Notes on the Ahl-i Haqq of the Guran district'. Bektachiyya: études sur l'ordre mystique des Bektachis et les groupes relevant de Hadji Bektach, Istanbul: Éditions Isis, 117-138.

Centers for Disease Control (CDC). (1991). Public health consequences of acute displacement of Iraqi citizens--March-May 1991. MMWR. Morbidity and mortality weekly report, 40(26), 443.

Chapman, C. (2008). Why a minority rights approach to conflict? The case of Southern Sudan Minority Rights Group International, April 2008. (Web) . $\begin{array}{llll}\text { Accessed in } & \text { October }\end{array}$ https://www.refworld.org/pdfid/483aab3f2.pdf

Daraj Multimedia. (2018). Yarsan: Marginalization in Iran and Displacement in Iraq. Daraj Magazine. (Web), Access Date: September 14, 2020.

Fahmi Kaka'i (2018). An introduction to Yarsan religion. Shikar Journal. Kurdistan women Unity. Autumn vo. (24). 107-126

Falak Al Din Kakai. (2013). Atraf Al Hadeth with Falak Al Din Kakai "T. V Show". Al Sharqia T.V. Access Date: May 2nd 2019. https://www.youtube.com/watch?v=pF0BtGX4Su4

Foltz, R. (2013). Two Kurdish Sects: The Yezidis and the Yarsan. Religions of Iran: From Prehistory to the Present. p. 219. ISBN 978-1-78074-307-3. https://www.lehmanns.de/shop/geisteswissenschaften/266210909781780743073-religions-of-iran

Gross R.ita M. Gross (1993). Buddhism after patriarchy: A feminist history, analysis, and reconstruction of Buddhism. State University of New York Press. p. 148. ISBN 978-1-4384-0513-1 
Gurr, T. R. (1993). Why minorities rebel: A global analysis of communal mobilization and conflict since 1945. International Political Science Review, 14(2), 161-201.

Hawary, A. K. (2021). The apparent shadow of the inner. (Inner. (2nd ed.). Yarsan Organization. 62-77.

Hawramy, N. (2011). Yarsan Women Texts in Yarsani Books. First edition. Kamal Publisher- Sulaimaniyah, Kurdistan, Iraq.

Hosseini, S. (2018). The Kaka 'i: A Religious Minority in Iraq. Contemporary Review of the Middle East, 5(2), 156-169.

Hosseini, S. H. (2017). Yarsan Religion and Oppression of the Era. Yarsan Democratic Organization. (Iran). July 9, 2017.Access date: May, 22th, 2019. Retrieved from http://www.yarsanmedia.org/ku/?p=4800

Ibrahim, M. (2015). The bomb of minorities in Iran and the spark of Mahabad. AlMugtama Magazine. (Web). May 20, 2015.

Jackson, A. V. W. (2003). Zoroastrian Studies: The Iranian Religion and Various Monographs (1928). Kessinger Publishing. p. 224. ISBN 978-0-76616655-4

Jamal, P. (2019). Danger of ISIS is not Leaving the Kaka'is. Kurdistan Standerd News. (News Channel). Accessed February 28th 2019. http://skurd.net/2019/07/07/

Juergensmeyer, M., \& Roof, W. C. (2011). Encyclopedia of global religion. Sage publications. SAGE Publications. ISBN 978-1-4522-6656-5.

Kaka'is Holy book "Saranjam". Kaka'is Holly Books collection called Saranjam. Written in Gorani Language.

Kirkuknow. (March, 2020). Daquq; Seventh Kakai village evacuated amid insurgent groups, three villages remain with few people. News website. Access Date September 14, 2021. Retrieved from https://kirkuknow.com/en/news/61650

Kreyenbroek, P. G. (2015). The Yezidi and Yarsan traditions. The Wiley Blackwell Companion to Zoroastrianism, 499-504.

Kreyenbroek, P., Alliso, C., \& Mir-Hosseini, Z. (2017). Yarsani Religion - Beliefs and Practices. Servant Group International. Access date: September 9, 2021. Retrieved from: https://servantgroup.org/yarsani-religion-beliefsand-practices/

Lalani, M. (2010). Still targeted: Continued persecution of Iraq's minorities. Minority Rights Group International. https://minorityrights.org/wpcontent/uploads/old-site-downloads/download-942-Download-this-reportin-ENGLISH.pdf

Lamani, M. (2009). Minorities in Iraq: The other victims. Centre for International Governance Innovation (CIGI) Special Report.

Laumakis Stephen S. J. Laumakis (2008). An introduction to Buddhist philosophy. Cambridge University Press. ISBN 978-1-139-46966-1. 
Mahdi Kakei. (2017). (Aalawi Religion is an Extension of Yazdani Religion. Kurdish History. First Edit. June 9, 2017. (WEB). Accessed August 14, 2018.

Minority rights Group International. (2017). Kaka'i in Iraq. World Directory of Minorities and Indigenous Peoples. Retrieved from https://minorityrights.org/minorities/kakai/

Minority rights Group International. (2018). Minorities and indigenous peoples in Iraq. World Directory of Minorities and Indigenous Peoples. Retrieved from http://minorityrights.org/country/iraq/

Mohammed, Z. J. (2018). An ancient Kurdish Religion: Yarsan. International Journal of Kurdish Studies 4 (2), 595-624. doi: 10.21600/ ijoks.454576

Özoğlu, H. (2004). Kurdish notables and the Ottoman state: Evolving identities, competing loyalties, and shifting boundaries. SUNY Press. https://books.google.iq/books?hl=en\&lr=\&id=vEAu4L1oz

Pascoe, E. A., \& Richman, S, L. (2009). Perceived discrimination and health: a meta-analytic review. Psychological bulletin, 135(4), 531.

Qaytuli, S. A. (2008). Arabization of Khanaqeen District from a Geopolitical Point of View. Sulaymaniyah; Teshk Press.

Robins, M., Tremewan, L. (2004). Persecution of Kaka'i Prior to and after 2003 in and around Karbala. Refugee Status Appeals Authority of New Zealand, $\begin{array}{llll}\text { Refugee } & \text { Appeal No. } & \end{array}$ https://www.refworld.org/cases,NZL_RSAA,477cfba70.html

Rostam, A. (2006). Yarsan: A religious-historical study. First edition. Qan'a Publishing office, Kurdistan, Iraq.

Rudaw. (2020). Kakai villages emptied by ISIS attacks in Khanaqin. Rudaw News Website. Access Date: September 8, 2021. Retrieved from: https://www.rudaw.net/english/middleeast/iraq/27092020

Saadun, M. (2016). A Small Religious Group in Iraq Carries Weapon Unlike the “Adults”. Rassef22, Political. (Web). Accessed February 13th 2019.

Sadoon, M. (2018). The impossible situation of Iraqi Kakai. CFI Media Development. Access date: September 7, 2021. Retrieved from: https://cfi.fr/en/news/impossible-situation-iraqi-kakai

Salloum, S. (2013). Minorities in Iraq. Masarat for Cultural and Media Development. 1st edition. Baghdad, Iraq. 222-230.

Salloum, S. (2015). A Hundred Illusions about Minorities in Iraq. Masarat for Cultural and Media Development. 1st edition. Baghdad, Iraq. 39-41

Salloum, S. (2017). Encyclopedia about Minorities in Iraq. Masarat for Cultural and Media Development. 1st edition. Baghdad, Iraq.

Schmitt, M. T., Branscombe, N. R., Postmes, T., \& Garcia, A. (2014). The consequences of perceived discrimination for psychological well-being: a meta-analytic review. Psychological bulletin, 140(4), 921.

Shawais, H. (2011). Baba Tahir Hamadani. Kominar Academia for Social Sciences. $\begin{array}{llll}\text { Retrived in } & \text { January } & \text { 10 th }\end{array}$ https://www.komunar.net/ar/index.php?sys=nuce \&dw=nivis \&id=339 
Svirsky, M. (2016). Exclusive: Kakai Minority Risks Eradication in Iraq. Clarion Project. (USA). Access Date: August 28, 202016. Retrieved from https://clarionproject.org/exclusive-kakai-minority-risks-eradication-iraq/

UNAMI. (2019). Human Rights Violations and Abuses in the Context of Demonstrations in Iraq. (Web), Accessed 1st February 2019. https://www.ohchr.org/Documents/Countries/IQ/Demonstrations-IraqUNAMI-OHCHR-report.pdf

Unrepresented Nations and Peoples Organization (UNPO). IRAQ: The situation of ethnic and religious minorities. Briefing paper D-IQ Meeting, European Parliament-Brussels. 20 June 2013.

Wang, H. (2012). Religious diversity in the Middle East before christianity. Overseas English, (18), 287-288.

Yari-Yarsan (2013). Murder of a Yarsani family. (Video file). Retrieved from https://www.facebook.com/yari.yarsan.tayfesan/videos/680421498646573/

NAZDAR QUDRAT ABAS, MSc. Psychiatric and Mental Health Nursing, is director of Gender Equality Center a Lecturer at Psychology Department, University of Garmian, Kurdistan Region of Iraq. Her area of focus includes mental health of forcibly displaced persons, minorities and women. Email: nazdar.qudrat@garmian.edu.krd

DILSHAD JAFF, MD, MPH, is a program coordinator for solutions to complex emergencies with the Gillings School's Research, Innovation and Global Solutions unit, as well as an adjunct assistant professor in the Department of Maternal and Child Health. He is an expert in complex humanitarian crises and conflict resolution. Email: jdilshad@email.unc.edu

HASHEM M. KARAMI, has been a lecturer at the University of Garmian (Kurdistan Region-Iraq), since 2012. His research interest focuses on Kurdish issues in the Middle East. Hashem has translated five books from English to Persian and/or Kurdish and has written several political columns in Persian and Kurdish. He has been a member of the editorial board of the online Politeia Journal from 2018 which focuses on the Kurdish issue. Email: h.karami@garmian.edu.krd 